UDK: 929Buić, M

\title{
Mirko Buić (1894. - 1967.): biografska skica splitskoga gradonačelnika i bana Primorske banovine
}

\author{
MARIJAN ČIPČIĆ \\ Muzej grada Splita \\ Split, Hrvatska \\ marijan.cipcic@mgst.net
}

\begin{abstract}
Ovaj rad na temelju neobjavljenih izvora, periodike, tiskane građe te referentne literature donosi rekonstrukciju dijela biografije Mirka Buića, pravnika, poduzetnika, publicista te visokoga lokalnog i državnog dužnosnika za vrijeme Kraljevine Jugoslavije. U profesionalnom smislu najdublji je trag ostavio u Trgovačko-obrtničkoj komori u Splitu, u kojoj je djelovao kao tajnik od kraja 1924. pa sve do sredine 1938. godine. Pred kraj međuratnoga razdoblja (1938. - 1939.) Buić je obnašao dužnosti splitskoga gradonačelnika, ministra tjelesnoga odgoja Kraljevine Jugoslavije te bana Primorske banovine. Njegova politička orijentacija bila je unitarno jugoslavenska i prorojalistička premda nije aktivno sudjelovao u stranačkom životu međuratnoga Splita. Buić je ostavio važan trag u splitskom sokolskom društvu, u kojem je imao rukovodeću ulogu između svjetskih ratova.
\end{abstract}

Ključne riječi: Mirko Buić; Split; pravnik; gradonačelnik; ban; ministar; Primorska banovina; Kraljevina Jugoslavija; Trgovačko-obrtnička komora; sokolsko društvo

\section{Uvod}

Za biografije najistaknutijih splitskih političara i gradonačelnika iz prve polovine XX. stoljeća poput Ive Tartaglie, Ante Trumbića i Josipa Smodlake u historiografskom smislu može se reći da su dobro istražene i prezentirane javnosti. Njihovi životopisi obrađeni su u zasebnim biografskim monografijama i zbornicima ${ }^{1}$ ili u sklopu djela koja se bave povijesti Splita i Dalmacije

\footnotetext{
1 U nastavku navodim izbor monografija koje su se bavile Tartagliom, Trumbićem i Smodlakom. MACHIEDO MLADINIĆ, Životni put Ive Tartaglie; JAKIR, BULJAN, Ivo Tartaglia: političar i intelektualac; KOVAČIĆ, dr. Ivo Tartaglia (1880.-1949.); SMITH PAVELIĆ, Dr. Ante Trumbić; PETRINOVIĆ, Ante Trumbić; PERIĆ, Ante Trumbić na dalmatinskom političkom poprištu; BOBAN, JELIĆ, Život i djelo Ante Trumbića; KOVAČIĆ, TROGRLIĆ, Dr. Ante Trumbić; ČIPČIĆ, PERKO KERUM, DUKIĆ, Ante Trumbić - Patricij s Lučca; ČIPČIĆ, Ante Trumbić - biografski fragmenti i nasljeđe; SMODLAKA, Zapisi; PERIĆ, SIROTKOVIĆ, „Politička djelatnost i politički lik Josipa Smodlake”.
} 
toga razdoblja. ${ }^{2} \mathrm{Za}$ dodatno rasvjetljavanje pojedinih segmenata političkoga, gospodarskoga i društvenoga života Splita toga doba svakako mogu poslužiti rekonstrukcije biografija ostalih gradonačelnika i utjecajnih splitskih političara koje do sada nisu bile u fokusu historiografskih istraživanja. Među takve biografije zasigurno spada i ona splitskoga načelnika i bana Primorske banovine dr. Mirka Buića.

Buiću nije posvećena pozornost u Hrvatskom biografskom leksikonu ni u Hrvatskoj enciklopediji, za razliku od njegovih prethodnika na banskoj dužnosti Primorske banovine Ive Tartaglie ${ }^{3}$ i Josipa Jablanovića. ${ }^{4}$ U publikaciji Splitsko iverje 1882-1941 iz 1983. autora Joška Barića i Šimuna Jurišića među biografijama važnih osoba iz toga razdoblja nalazi se i ona o Buiću. ${ }^{5} \mathrm{U}$ prigodnoj publikaciji o znamenitim Splićanima autora Petra Požara, izdanoj 2001. povodom obilježavanja 1700 godina Splita, Buićeva biografija također je našla svoje mjesto među životopisima ostalih znamenitih Splićana, ${ }^{6}$ a zastupljena je i u monografiji Banovi Kraljevine Jugoslavije. Biografski leksikon, izdanoj 2019. u Beogradu. ${ }^{7}$

\section{Rođenje, školovanje i vjenčanje}

Mirko Buić rođen je 14. travnja 1894. godine. U matičnu knjigu rođenih upisan je punim imenom Mirko Giorgio Antonio. Otac mu je bio dr. Juraj Buić $^{8}$, liječnik i aktivni politički djelatnik tijekom narodnih previranja s početka XX. stoljeća, a majka Jozica ${ }^{9}$, kći prvoga narodnjačkog načelnika splitske

2 Primjerice JELASKA MARIJAN, Grad i ljudi: Split 1918.-1941.; JAKIR, Dalmacija u meduratnom razdoblju; ČIPČIĆ, Splitski gradonačelnici (1882. - 1918.).

3 „Tartaglia, Ivo”.

4 PRANJKO, „Jablanović, Josip”, 212.

5 BARIĆ, JURIŠIĆ, Splitsko iverje 1882-1941, 8.

6 POŽAR, Znameniti i zaslužni Splićani, 66.

7 GULIĆ, „Buić Mirko”, 37-38.

8 Juraj Buić (Stari Grad, 1861. - Split, 1910.), liječnik i političar. Sin Antonija Buića, pomorca, i Laure rođ. Plančić. Njegovi roditelji vjenčali su se 1845. u Starom Gradu. Nakon smrti prve supruge Luigie rođ. Bortolotti Juraj se oženio Jozicom rođ. Rendić-Miočević, s kojom je dobio sina Mirka. Kao mladi student medicine bio je aktivan u narodnjačkim inicijativama u Starom Gradu. Bio je redoviti član Hrvatske čitaonice 1882. godine. Iste godine jedan od brojnih čestitara koji su brzojavima čestitali pobjedu Narodnoj stranci na izborima za splitsko Općinsko vijeće. Bio je angažiran oko izgradnje zgrade Hrvatskoga doma u Starom Gradu, koji je podiglo istoimeno dioničko društvo 1893. godine. Buić je s trojicom kolega kontrolirao upravljanje sredstvima toga dioničkog društva. Početkom 1890-ih Juraj Buić seli se u Split. U izvorima iz 1897. navodi ga se kao općinskoga liječnika uz dr. Vinka Righija. HR-DAST179-MK, sign. 714, Stari Grad, str. 32, upis pod rednim brojem 18.; DOMAZET, Stari Grad na Hvaru, 81, 86; NOVAK, Povijest Splita, knj. 3, 359; BEZIĆ-BOŽANIĆ, „SPLIT A. D. 1897.”, 200.

9 Jozica Buić rođ. Rendić-Miočević (Split, 1874. - Split, 1907.). Preminula je u 33. godini od zatajenja srca. HR-DAST-179-MK, sign. 609, sv. Duje, str. 49, upis pod rednim brojem 44. 
Općine dr. Duje Rendić-Miočevića. ${ }^{10}$ Krstio ga je don Frane Bulićl1 6 . svibnja 1894. u crkvi sv. Dujma. Roditelji su mu se vjenčali u istoj crkvi 11. listopada 1891. godine. Očev kum na vjenčanju bio je istaknuti dalmatinski preporodni političar Juraj Biankini. ${ }^{12}$ Nakon završene osnovne i srednje škole Buić je studirao pravo u Beču, Pragu i Zagrebu, gdje je stekao doktorat iz pravnih znanosti. ${ }^{13}$ Oženio se Vjekoslavom Plazibat 24. ožujka 1923. u Splitu. ${ }^{14}$ Mirko i Vjekoslava Buić, koliko je poznato, dobili su troje djece: sinove Đorđa ${ }^{15} \mathrm{i}$ Miroslava ${ }^{16}$ te kćer Jagodu ${ }^{17}$.

10 Duje Rendić-Miočević (Split, 1834. - Split, 1915.), pravnik i političar. Zastupnik Narodne stranke u Dalmatinskom saboru u Zadru i Carevinskom vijeću u Beču. Godine 1882. na izborima za splitsko Općinsko vijeće Narodna stranka pobijedila je Autonomnu stranku dugogodišnjega splitskog načelnika Antonija Bajamontija. Za prvoga narodnjačkog načelnika izabran je Duje Rendić-Miočević, a tu je dužnost obnašao do 1885. godine. RENDIĆ-MIOČEVIĆ, „Dr. Duje Rendić Miočević”, 13-38.

11 Frane Bulić (Vranjic, 1846. - Zagreb, 1934.), arheolog, povjesničar, konzervator, publicist i političar. Godine 1883. imenovan je za ravnatelja Klasične gimnazije u Splitu, upravitelja Arheološkoga muzeja te konzervatora za splitsko područje. Od 1912. do 1925. obnašao je dužnost konzervatora zaduženog za područje Dalmacije. U političkoj sferi Bulić je bio poslanik u Dalmatinskom saboru u Zadru i Carevinskom vijeću u Beču. „Bulić je naš prvi arheolog svjetskog glasa te istodobno jedan od posljednjih polihistora.” CAMBI, STIPČEVIĆ-DESPOTOVIĆ, „Bulić, Frane”.

12 Za pomoć pri pretraživanju arhivskih dokumenata iz Državnoga arhiva u Splitu zahvaljujem kolegici Haniji Mladineo Mika. HR-DAST-179-MK, sign. 582, sv. Duje, str. 120, upis pod rednim brojem 50. Juraj Biankini (Stari Grad na Hvaru, 1847. - Split, 1928.), političar i publicist. Od 1871. do 1918. uređivao je Narodni list, glasilo Narodne stranke u Dalmaciji. Bio je zastupnik u Dalmatinskom saboru u Zadru i Carevinskom vijeću u Beču; član Privremenoga narodnog predstavništva (1918.) i potpredsjednik Vlade Kraljevine SHS Ljube Davidovića; član Jugoslovenske demokratske stranke i poslije Samostalne demokratske stranke. Bio je prvi predsjednik društva „Jadranska straža” (1923. - 1928.). OBAD, „Biankini, Juraj”.

13 Premda se u kratkoj biografiji objavljenoj u splitskoj tiskovini Novo doba prilikom imenovanja Mirka Buića za splitskoga načelnika navodi da je osnovnu i srednju školu završio u Splitu, uvidom u brojne školske spomenice te objavljenu i neobjavljenu građu splitskih gimnazija i trgovačke škole iz razdoblja kada je Buić bio đak nisam uspio doći do detaljnijih podataka o njegovu školovanju. „Postavljanje nove općinske uprave u Splitu”, Novo doba (Split), 11. 6. 1938., 6.

14 HR-DAST-179-MK, sign. 582, sv. Duje, str. 120, upis pod rednim brojem 50.

15 Đorđe Buić poginuo je u Drugom svjetskom ratu obnašajući dužnost osobnoga prevoditelja sina britanskoga premijera Winstona Churchilla. Jagoda BUIĆ, „Intervju: Moralnim zločincima Mani Gotovac i Jagodi Martinčević nikada neću oprostiti”, Nacional (Zagreb), on-line izdanje, 7. 7. 2015., pristup ostvaren 9. 4. 2020., https://www.nacional.hr/jagoda-buic-moralnim-zlocincima-mani-gotovac-i-jagodi-martincevic-nikada-necu-oprostiti.

16 Miroslav Buić preminuo je kao dijete početkom 1926. godine. „Vijesti iz Župe Split”, Sokol na Jadranu (Split), ožujak 1926., 66.

17 Jagoda Buić (Split, 1930.), umjetnica, kostimografkinja i scenografkinja. Realizirala je brojne domaće i međunarodne izložbe, a za svoj rad dobila brojna međunarodna priznanja. TARTAGLIA-KELEMEN, „Buić, Jagoda”. 


\section{Tajnik u Trgovačko-obrtničkoj komori u Splitu, publicist i poduzetnik}

Po završetku sudsko-advokatske i trgovačke prakse Buić se zaposlio u Trgovačko-obrtničkoj komori u Splitu, u kojoj je obnašao dužnost tajnika od 1924. godine. Prema odredbi Privremenoga izbornog pravilnika za Trgovačko-obrtničku komoru u Splitu iz 1922., Komora je bila ustrojena u dva odjela i šest odsjeka. Trgovačko-pomorski odjel sastojao se od odsjeka trgovine na veliko, pomorstva i ostale trgovine, a industrijsko-rudarski odjel uključivao je odsjek tvorničke industrije od 50 radnika, odsjek rudarstva te odsjek ostalih obrtnih pothvata. ${ }^{18}$ Buić je za tajnika izabran nakon umirovljenja dr. Gaje Bulata ${ }^{19}$, koji je tajničku dužnost obavljao od 1890. godine. Na komorskoj sjednici održanoj 28. listopada 1924. odlučeno je da će se otvoriti dva tajnička mjesta na probni rok od godinu dana. ${ }^{20}$ Natječaj za dva komorska tajnika objavljen je u Službenom glasniku: zvaničnom listu Splitske i Dubrovačke oblasti 8. studenog 1924. godine. Kao uvjet za zaposlenje navedeno je da budući tajnici moraju imati završen pravni fakultet. ${ }^{21} \mathrm{Na}$ redovitoj komorskoj sjednici održanoj 18. prosinca 1924. Buić je izabran za tajnika zajedno sa Savom Boškovićem. ${ }^{22}$ $\mathrm{Na}$ temelju zakona o činovnicima i sucima, godišnja tajnička plaća 1929. s dodatkom za mirovinu za Buića i Boškovića iznosila je 26.070 dinara. ${ }^{23}$ Do 1934. tajnici su bili izjednačeni po funkciji, a od tada je Bošković bio nadređen Buiću kao glavni tajnik. ${ }^{24}$ Buić je na komorskim sjednicama izvještavao o provedbi zadataka za koje je bio zadužen. ${ }^{25} \mathrm{U}$ Komori je Buić, osim redovnih tajničkih poslova, obavljao i ostale specifične zadatke. Među ostalim, zauzimao se za postavljanje temelja praćenja domaće pomorske statistike. ${ }^{26}$

18 FRIEDL, Gospodarska komora u Splitu 1808.-2008., 31.

19 Gajo Bulat (Zadar, 1867. - Split, 1927.), pravnik, trgovinski dužnosnik, prevoditelj i političar. Pravo je doktorirao u Grazu. Od početka sokolskoga pokreta u Splitu 1893. bio je aktivan u tom društvu. Zastupnik u Dalmatinskom saboru od 1910. godine. U Kraljevini SHS bio je član Demokratske, a potom i Samostalne demokratske stranke. Bavio se publicističkim radom i prevođenjem na talijanski jezik. IVANIŠEVIĆ, „Uglednici iz splitskog roda Bulata”, 56.

20 Zapisnik II. redovite komorske sjednice održane 28 listopada 1924 godine, 31-33.

21 Službeni glasnik: zvanični list Splitske i Dubrovačke oblasti (Split), 8. 11. 1924., 2.

22 Ukupno je bilo sedam kandidata za komorskoga tajnika. Uz Buića i Boškovića, to su bili: Ante Vučinović, dr. Krunoslav Bego, dr. Ante Mikulić, dr. Niko Ivanović i Dragutin Korlaet. Jedino su Buić i Bošković dobili natpolovičnu većinu glasova vijećnika. Od 29 vijećnika, Buić je dobio 21 glas, a Bošković 16 glasova; HR-DAST-91-TOK, kut. 519, „Zapisnik III. redovite komorske sjednice održane 18 prosinca 1924 godine".

23 HR-DAST-91-TOK, kut. 610, „Preglednica sadašnjeg stanja osoblja dodijeljenog uredu Trgovačke i obrtničke komore u Splitu, ur. br. 2634/5, 1929".

24 Zapisnik II. redovite komorske sjednice održane dne 11. oktobra 1934., 2.

25 Posljednja komorska sjednica na kojoj je Buić sudjelovao kao tajnik održana je 18. svibnja 1938. godine. Idućega mjeseca imenovan je za splitskoga gradonačelnika. Zapisnik I. redovite plenarne sjednice Trgovinsko industrijske komore u Splitu, održane 18. svibnja 1938.

26 „Postavljanje nove općinske uprave u Splitu”, Novo doba, 11. 6. 1938., 6; „Novi ban Primorske banovine", Glasnik Primorske banovine (Split), 1. 10. 1938., 194. 
Kako Direkcija pomorskog saobraćaja nije imala ljudske resurse za prikupljanje i publiciranje pomorske statistike, te je poslove preuzela Trgovačko-obrtnička komora. ${ }^{27}$ Pomorska statistika pratila se tako da se statistički materijal preko Direkcije pomorskog saobraćaja mjesečno dostavljao komorskom statističkom odsjeku. No kod pojedinih lučkih kapetanija utvrđeni su nedostaci u prikupljanju statističkih podataka, na koje su iz Komore često upozoravali nadležnu Direkciju, nudeći pritom savjete za poboljšanje toga procesa. $^{28}$

Buić je kao tajnik Trgovačko-obrtničke komore sudjelovao u raspravama vezanim za razne privredne probleme. Posebno se bavio pitanjem razvoja industrije u Splitu i njegovoj okolici te pitanjima prometa i međunarodne trgovine. Tijekom toga vremena djelovao je u ustanovama socijalnoga osiguranja i posredovanja rada. ${ }^{29}$

Dok je obnašao dužnost tajnika, izgrađena je zgrada Komore na Trumbićevoj obali. Buić je bio administrativna podrška Odboru za izgradnju, koji je izabran u ožujku 1927. godine. ${ }^{30}$ Buić je o radu Odbora izvijestio komorske vijećnike na redovnoj sjednici održanoj u travnju 1928. godine. ${ }^{31}$ Ukupno je tijekom 1928. održano 11 sjednica Odbora za izgradnju komorske zgrade na kojima su se rješavala razna pitanja realizacije toga projekta. ${ }^{32}$ Buić je sudjelovao u radu ocjenjivačkoga suda imenovanog početkom 1929. za odabir natječajnih projekata kao osoba zadužena za informiranje. ${ }^{33}$ Nakon provedenih natječaja za projektanta je izabran Fabijan Kaliterna, a za izvođača radova ovlašteni građevinski inženjer Žarko Dešković. Radovi na zgradi započeli su u travnju 1930., a dovršeni su početkom lipnja 1931. godine. Zgrada se vizualno i funkcionalno uklopila u okruženje u kojem je sagrađena uz prirodnu ribarsku lučicu Matejušku. ${ }^{34}$ Iz sačuvanih ponuda naslovljenih na Mirka Buića vidljivo je da je on bio zadužen za nabavu uredske opreme za novu zgradu Trgovačko-obrtničke komore u Splitu. ${ }^{35}$

Buić se bavio i publicističkim radom i napisao je niz stručnih članaka i studija iz gospodarstva. ${ }^{36}$ Bio je i urednik ekonomskoga tjednika Privred-

27 HR-DAST-91-TOK, kut. 880, „Dopis Trgovačko-obrtničke komore u Splitu, br. 4009, 26. siječnja 1928".

28 HR-DAST-91-TOK, kut. 880, „Dopis Trgovačko-obrtničke komore u Splitu, br. 2276/3, 26. studenog 1929".

29 „Postavljanje nove općinske uprave u Splitu”, Novo doba, 11. 6. 1938., 6; „Novi ban Primorske banovine", Glasnik Primorske banovine, 1. 10. 1938., 194.

30 PIPLOVIĆ, „Izgradnja doma Trgovačke i obrtničke komore u Splitu”, 195-198.

31 HR-DAST-91-TOK, kut. 643, „Zapisnik I. redovite komorske sjednice održane dneva 12 aprila 1928".

32 Izvještaj Trgovačko-obrtničke komore za god. 1928.-1928., 46.

33 HR-DAST-91-TOK, kut. 643, „Zapisnik sjednice ocjenjivačkog suda natječajnjih projekata za zgradu Trgovačko-obrtničke komore u Splitu, 9. ožujka 1929”.

34 PIPLOVIĆ, „Izgradnja doma Trgovačke i obrtničke komore u Splitu”, 198-200.

35 HR-DAST-91-TOK, kut. 643, „Ponuda tvrtke Simens d.d. za telefonske uređaje, 7. siječnja 1931.”; „Ponuda tvrtke Express za ručne sprave za gašenje vatre, 28. ožujka 1931”.

36 „Novi ban Primorske banovine”, Glasnik Primorske banovine, 1. 10. 1938., 194. 
nička riječ, koji je započeo izlaziti krajem listopada 1928. godine. U prvom broju navodi se glavni cilj njegova pokretanja: „Naš cilj će biti, da objektivnom, stvarnom i bezobzirnom kritikom općeg ekonomskog stanja u državi, a specijalno u našem gradu, probudimo interes javnosti za sve aktuelne ekonomsko-socijalne probleme." ${ }^{37}$ Iz zapisnika promicateljskoga odbora za osnivanje Privredničke riječi, objavljenog u prvom broju, vidljivo je da se inicijativa za pokretanje lista pojavila četiri mjeseca prije izlaska prvoga broja. Tada je dogovoreno da će list izdavati mjesne zadruge kao svoje glasilo. No, kako se kaže u zapisniku, problem je bio što veći broj mjesnih trgovaca tada još nije bio udružen. Naposljetku se odustalo od inicijalne ideje da list bude glasilo zadruga i odlučeno je da će se obratiti cjelokupnom trgovačko-obrtničkom staležu, pa je u skladu s tim i dobio podnaslov Tjednik za promicanje interesa trgovačko-obrtničkog staleža. ${ }^{38}$

Glavni razlog zbog kojega je list pokrenut baš krajem listopada vjerojatno leži u tome što su se za općinske izbore u Splitu 18. studenog 1928. kandidirali privrednici sa svojom listom, pa im je Privrednička riječ poslužila kao glasilo u predizbornoj kampanji. ${ }^{39}$ Predsjednik promicateljskoga odbora za osnivanje lista i vlasnik konzorcija izdavača Privredničke riječi bio je industrijalac Josip Pijević, zamjenik na listi privrednika. Njega je na čelu konzorcija lista početkom travnja 1929. naslijedio trgovac Lovro Casolini, koji je ujedno bio nositelj liste privrednika. ${ }^{40}$ Privrednicima je gradonačelnik Ivo Tartaglia ponudio izlazak na izbore zajedno s njegovom listom, što su oni odbili. ${ }^{41} \mathrm{Na}$ kraju je nezavisna lista privrednika na izborima za splitsko Općinsko vijeće ostvarila beznačajan rezultat sa samo 102 glasa $(1,46 \%) .{ }^{42}$

Početkom lipnja 1930. Buić je naslijedio Niku Bužančića na uredničkome mjestu Privredničke riječi, a tjednik je uređivao sve do posljednjega tiskanog broja u studenom 1932. godine. Buićevim preuzimanjem uredničke funkcije list mijenja podnaslov u Tjednik za trgovinu, pomorstvo, obrt $i$ industriju. ${ }^{43}$ Od tada zapravo djeluje kao neslužbeno glasilo Trgovačko-obrtničke komore u kojem su objavljivani brojni statistički podaci, razne predstavke Komore, kao i zapisnici s njihovih sjednica. ${ }^{44} \mathrm{U}$ listu su svoje stručne referate često

37 „Naša prva riječ”, Privrednička riječ (Split), 27. 10. 1928., 1.

38 „Zapisnik sjednice održane u nedjelju, dne 21. ov. mj. u Obrtničkom domu, u svrhu osnutka privredničkog lista”, Privrednička riječ, 27. 10. 1928., 2.

39 „Općina i politika”, Privrednička riječ, 3. 11. 1928., 1; „Samostalni istup privrednika u opć. izborima” i „Privrednička lista”, Privrednička riječ, 10. 11. 1928., 1.

40 Privrednička riječ, 6. 4. 1929., 4.

${ }^{41}$ „Istina o samostalnom istupu privrednika u opć. izborima”, Privrednička riječ, 10. 11. 1928., 2.

42 JELASKA MARIJAN, Grad i ljudi: Split 1918.-1941., 130.

43 Privrednička riječ, 8. 6. 1929., 1; Privrednička riječ, 27. 10. 1928., 1; MOROVIĆ, Građa za bibliografiju splitske periodike, 34 .

44 U jednom dopisu Trgovačko-obrtničke komore iz Splita uredništvu mjesečnika Privreda u Zagrebu navodi se da Privrednička riječ nije službeni glasnik splitske Komore, „ali se iz Komore davaju redakciji ovog lista sve informacije, podatci i predstavke, u koliko su za javnost, pa dok Komora nema svoj bilten, ovaj ga sedmičnik donekle nadomještava, jer uredniš- 
objavljivali komorski tajnici Savo Bošković i Mirko Buić. Nakon što je posjetio poljsku luku Gdyniu Buić je u seriji feljtona u rujnu i listopadu 1929. objavio historijat razvoja te luke u Baltičkome moru uz detaljne faktografske i statističke podatke. ${ }^{45}$

Od rujna 1932. list je reducirao mjesečni broj izlazaka na svaki 10. u mjesecu. Od tada u podnaslovu više ne stoji Tjednik nego List za trgovinu, pomorstvo, obrt i industriju. ${ }^{46}$ Posljednji broj izašao je sredinom studenoga 1932. godine. ${ }^{47}$ Uzročno-posljedični razlozi prestanka tiskanja Privredničke riječi najvjerojatnije su povezani s gospodarskom krizom koja se početkom 30-ih godina reflektirala na cjelokupno gospodarstvo Kraljevine Jugoslavije.

Buić je bio jedan od glavnih dioničara društva Ruda dioničko društvo Split, osnovanog u lipnju 1920. s temeljnom glavnicom od 4 milijuna kruna. Ostali glavni dioničari bili su Zekan, Grochowalski, Lavš i Tripalo. Oni su ukupno imali 89 \% dionica. Jedno je vrijeme Buić bio na čelu uprave toga društva. ${ }^{48}$

U ožujku 1932. osnovana je Privredno-gospodarska zadruga Primorske banovine u Splitu, a Buić je izabran za člana njezine uprave. Osnivanje Zadruge potaknuto je lošim gospodarskim prilikama u Primorskoj banovini. Primarni joj je cilj bilo osiguranje usjeva i plodova, a kao općeniti cilj navodi se rad na poboljšanju gospodarskih prilika na području Primorske banovine. Buić je, kao i ostali dužnosnici, svoju dužnost u Zadruzi obnašao besplatno. ${ }^{49}$

\section{Djelovanje u sokolskom društvu}

Buić je tijekom života bio posebno vezan uz sokolsko društvo u Splitu, u kojem je ostavio duboki trag kao istaknuti rukovoditelj. Svoj rad u njemu započeo je još prije Prvoga svjetskog rata, a to sportsko društvo, čije se djelovanje proširilo u slavenskim zemljama Austro-Ugarske, u Splitu je osnovano 26. siječnja 1893. pod nazivom Hrvatski sokol. ${ }^{50}$ Godine 1908. splitsko sokolsko društvo dobilo je svoje prostorije u novosagrađenom Hrvatskom domu. ${ }^{51}$

tvo vodi računa o tome”. HR-DAST-91-TOK, kut. 610, Dopis uredništvu Privrede - mjesečnik Komore za Trg. Obrt. i Ind. Zagreb - saradnja, 26. prosinca 1931., ur. broj: 3097; HR-DAST91-TOK, kut. 595, Dozvole izdane za područje T.O.K. Split kroz novembar 1929., br. 2689. S naznakom za „Privredničku Riječ”.

45 Mirko BUIĆ, „Razvoj i ekspanzija luke Gdynia u poljskom Baltiku”, nastavci I-IV, Privrednička riječ, 14. 9. 1929., 2; 21. 9. 1929., 2; 28. 9. 1929., 2; 12. 10. 1929., 2.

46 Privrednička riječ, 10. 9. 1932., 1.

47 Privrednička riječ, 16. 11. 1932., 1.

48 JELASKA MARIJAN, Grad i ljudi: Split 1918.-1941., 217-218.

49 Privrednička riječ, 14. 4. 1932., 2-3.

50 Prvi sokolski starješina Hrvatskoga sokola u Splitu bio je Vinko Katalinić. ČIPČIĆ, „Splitski gradonačelnik Vinko Katalinić”, 203; JELASKA MARIJAN, Grad i ljudi: Split 1918. 1941., 470.

51 RADICA, Novi Split, 315. Zgrada Hrvatskoga doma u Splitu u kojoj su smještena kulturno-umjetnička i sportska društva izgrađena je prema projektu arhitekta Kamila Tončića. BUBLE, „Hrvatski dom Kamila Tončića u Splitu”, 420. 
Tijekom studija u Pragu Buić je bio član češkoga sokolskog društva. Nakon rata nastavio je svoju aktivnost u Jugoslavenskom sokolskom savezu, u kojem je bio dugogodišnji član uprave. Radio je na stvaranju i učvršćivanju veza s Bugarima, Čehoslovacima i Poljacima. Obnašao je i dužnost predsjednika Jugoslavensko-bugarske lige. ${ }^{52}$

Nakon završetka Prvoga svjetskog rata pokrenuto je pitanje ujedinjenja sokolskih društava na teritoriju nove države. U tim su inicijativama prednjačila sokolska društva u Dalmaciji, koja su već tada mijenjala svoje nazive dodajući im pridjev ,jugoslavenska”. ${ }^{33}$ Nakon sjednice Prvoga sokolskog sabora Kraljevstva Srba, Hrvata i Slovenaca (SHS), održanog u lipnju 1919., odlučeno je da će se sve postojeće lokalne sokolske organizacije raspustiti i da će se osnovati nove - jugoslavenske. Prema toj odredbi, raspuštena je splitska sokolska organizacija premda je ona još u ožujku 1919. promijenila hrvatsko ime u jugoslavensko. ${ }^{54}$

$\mathrm{Na}$ čelu društva Buić je 1926. naslijedio dr. Vjekoslava Lavša. Buić je za vrijeme svojega vodstva znatno osuvremenio rad splitskoga sokolskog društva. Uveo je nove forme vježbanja i na taj način unio živost u stare vježbe, koje su bile definirane još prije Prvoga svjetskog rata. U dječju gimnastiku uveo je igru, za muške članove laku atletiku, a za članice ritmiku. Buićevom zaslugom napravljene su nove garderobe s tuševima u sokolani, a za vježbalište na otvorenom uređene su moderne sprave. ${ }^{55}$

Godine 1923. Buić je povodom 30-godišnjice osnutka sokolskoga društva u Splitu pokrenuo publikaciju Sletski vijesnik Sokolske župe Split, kojoj je bio i urednik..$^{56}$ Taj mjesečnik izašao je u šest brojeva radi promocije petoga sleta Sokolske župe u Splitu dogovorenog za 21. i 22. srpnja 1923. godine. ${ }^{57} \mathrm{Od}$ 1926. tiskana je mjesečna publikacija Sokol na Jadranu, koja je 1930. dosegnula nakladu od 2500 primjeraka diljem Kraljevine SHS, a bila je veoma čitana i među iseljeništvom. U njoj je Buić povremeno surađivao kao autor tekstova. ${ }^{58}$

Prigodom sedmoga sokolskog sleta splitske sokolske župe, održanog 5. rujna 1926., sokolski starješina Buić primio je zastavu kao dar kralja Aleksandra Karađorđevića. ${ }^{59}$ Od 13. do 29. lipnja 1931. održan je u Splitu najveći međunarodni sokolski slet na Jadranu. Buić je bio njegov idejni začetnik i predsjednik organizacijskoga odbora. Za tu manifestaciju Split je organizirao prihvat za preko 10000 sudionika sleta. Tom je prilikom na Katalinića brigu

52 „Postavljanje nove općinske uprave u Splitu”, Novo doba, 11. 6. 1938., 6; „Novi ban Primorske banovine", Glasnik Primorske banovine, 1. 10. 1938., 194.

53 JAKOVČEV, Sokolska organizacija u borbi za bratstvo jugoslavenskih naroda, 45 .

54 JELASKA MARIJAN, Grad i ljudi: Split 1918.-1941., 217-218, 471.

55 Javnu vježbu društva održanu pod Buićevim vodstvom 1921. Branislav Radica navodi kao primjer vrhunskoga gimnastičkog nastupa. RADICA, Novi Split, 319.

56 Sletski vijesnik Sokolske župe Split (Split), ožujak i travanj 1923., 1.

57 Sletski vijesnik Sokolske župe Split, ožujak i travanj 1923., 4; Sletski vijesnik Sokolske župe Split, 21. 7. 1923., 1.

58 RADICA, Novi Split, 317-320.

59 MAROVIĆ, RADJA, Povijest športa u Splitu, 508. 
bilo uređeno posebno šatorsko naselje. ${ }^{60}$ Toj manifestaciji, koja se odvijala u tri etape, posvećena je znatna pozornost u splitskoj dnevnoj tiskovini Novo doba. Prvi dan sleta započeo je igrama i nadmetanjima srednjoškolaca Primorske banovine. ${ }^{61} \mathrm{U}$ sklopu manifestacije održane su vježbe kopnene vojske i mornarice. ${ }^{62} \mathrm{U}$ završnom dijelu programa međunarodnoga sokolskog sleta u Splitu održane su masovne javne vježbe, a manifestacija je završena vatrometom te velikom povorkom sokolaša. Tom prigodom Buić je odlikovan srebrnim križem Legije časti Sokolskoga saveza Poljske. ${ }^{63}$ Iste godine vježbači splitske sokolske župe sudjelovali su na čelu sa svojim starješinom Buićem na velikom sletu u Pragu. ${ }^{64}$

Nakon uvođenja diktature kralja Aleksandra Karađorđevića 1929. zakonom su podržavljene sve lokalne sokolske organizacije. Sredinom 30-ih sokolske organizacije gube državnu potporu, a njihovo članstvo tih godina počinje znatno opadati. U takvim okolnostima brojne su sokolske jedinice zapale u probleme, uključujući i splitsku organizaciju. ${ }^{65}$ Buić je ostao na čelu splitskoga Sokola sve do konačnoga prestanka djelovanja te organizacije 1941. godine. ${ }^{66}$

\section{Politički nazori}

Buić je u mladim danima bio aktivan u jugoslavenskoj nacionalističkoj omladini. Bio je jedan od potpisnika proglasa Ujedinjene omladine u listu Sloboda u listopadu 1912. godine ${ }^{67}$ Organizacija osnovana 1921. u Splitu pod imenom Jugoslavenska napredna nacionalistička omladina (Orjuna), u znatnoj se mjeri ideološki naslanjala na predratnu ideologiju jugoslavenske nacionalističke omladine. Premda Mirka Buića pronalazimo i među članovima Orjune, nisam naišao na tragove njegova aktivnijega djelovanja u toj ekstremnoj nacionalističkoj organizaciji. ${ }^{68}$

Premda u političkom smislu nije bio aktivan u stranačkom životu međuratnoga Splita, Buić je pripadao krugu unitarno orijentiranih splitskih

60 Isto, 510

61 „Omladino zdravo!”, Novo doba, 13. 6. 1931., 1; „Slet sokolstva na Jadranu”, Novo doba, 15. 6. 1931., 5 .

62 „Slet sokolstva na Jadranu”, Novo doba, 22. 6. 1931., 5.

63 „Veliki sokolski dani u Splitu”, Novo doba, 29. 6. 1931., 1-5; Sokol na Jadranu, lipanj-srpanj 1931., 113-129.

64 MAROVIĆ, RADJA, Povijest športa u Splitu, 511.

65 JELASKA MARIJAN, Grad i ljudi: Split 1918.-1941., 472; JAKOVČEV, Sokolska organizacija u borbi za bratstvo jugoslavenskih naroda, 46-52.

66 JELASKA MARIJAN, Grad i ljudi: Split 1918.-1941., 501.

67 Sloboda je bila glasilo Hrvatske pučke napredne stranke, koju je vodio Josip Smodlaka. Među potpisnicima proglasa Ujedinjenje omladine bili su Tin Ujević, Marino i Oskar Tartaglia, Niko Bartulović i drugi. BOŠKOVIĆ, Orjuna - ideologija i književnost, 49.

68 BOŠKOVIĆ, Orjuna: ideologija i književnost, 84-85, 456. Buića kao člana Orjune navodi Niko Bartulović, splitski publicist i urednik Pobede - glavne tiskovine te organizacije. BARTULOVIĆ, Od revolucionarne omladine do Orjune. 
intelektualaca bliskih rojalističkim krugovima obitelji Karađorđević poput Ive Tartaglie ${ }^{69}$, dr. Jakše Račića ${ }^{70}$ i drugih. Razloge zbog kojih je znatan broj splitskih intelektualaca bio blizak vladajućim krugovima u Beogradu treba potražiti i u činjenici da je Split kao središte Dalmacije u prvom desetljeću nakon uspostave Kraljevine SHS prosperirao u gospodarskom, komunalnom i društvenom smislu. ${ }^{71}$

Buićevi politički nazori mogu se identificirati i zbog činjenice da je dugi niz godina bio čelnik splitskoga sokolskog društva. Premda je to društvo, uz sportsku, oduvijek imalo i određenu političku ulogu s naglašenom jugoslavenskom notom, od 1929. i Zakona o osnivanju Sokola Kraljevine Jugoslavije sve su lokalne organizacije, pa tako i splitska, poprimile karakteristike državnih ustanova s ciljem propagiranja ideje integralnoga jugoslavenstva. ${ }^{72}$ Kako je Buić i nakon toga ostao na čelu podružnice splitskoga Sokola, očito je da je u svojim političkim pogledima i dalje ostao na unitarnim stajalištima. Buić je 30-ih godina bio blizak režimskoj Jugoslavenskoj nacionalnoj stranci. U suprotnom zasigurno i ne bi mogao biti imenovan na odgovorne pozicije splitskoga načelnika, ministra u vladi i bana Primorske banovine. Uoči parlamentarnih izbora 1935. u određenim političkim kuloarima Buić se spominjao kao jedan od mogućih kandidata na režimskim listama nositelja Bogoljuba Jevtića za grad Split, no naposljetku ipak nije bio kandidiran. ${ }^{73}$

69 Ivo Tartaglia (Split, 1880. - Lepoglava, 1949.), političar, odvjetnik i publicist. Pravo je studirao u Zagrebu, Beču i Grazu. Od 1929. do 1932. ban Primorske banovine. Bio je jedan od utemeljitelja udruženja „Jadranska straža”. Nakon talijanske okupacije Splita (1941.) kao protivnik talijanske fašističke politike uhićen je i interniran na Liparske otoke (Italija). Komunističke su ga vlasti nakon Drugoga svjetskog rata uhitile pod optužbom da je podržavao diktaturu kralja Aleksandra Karađorđevića i osudile na zatvor, u kojem je i umro. MACHIEDO MLADINIĆ, Životni put Ive Tartaglie.

70 Jakša Račić (Vrbanj na otoku Hvaru, 1868. - Split, 1943.), liječnik i političar. Studirao je medicinu u Grazu, Pragu i Innsbrucku. Bio je pionirom upotrebe rendgenskoga aparata u Dalmaciji. Važna je bila Račićeva uloga pri uređenju Marjana. Kompromitirao se djelovanjem u vodstvu četničkoga stožera za vrijeme talijanske okupacije Splita u Drugom svjetskom ratu. Na Račića je u režiji splitskih komunista 18. kolovoza 1943. izvršen atentat, od čijih je posljedica umro nakon nekoliko dana. J. KOVAČIĆ, „Splitski liječnik i političar Jakša Račić”, 257-268.

${ }^{71}$ Kada je postajalo jasno da na državnoj razini vladajući krugovi ne namjeravaju riješiti problem hrvatskoga pitanja koji je tinjao sve od ujedinjenja 1918., određeni broj splitskih unitarista započeo se zalagati za decentralizaciju i federalizaciju države. Među njima je bio Ivo Tartaglia, koji se nakon ostavke na dužnost bana Primorske banovine 1932. u nekim svojim stajalištima približio Hrvatskoj seljačkoj stranci. JAKIR, Dalmacija u međuratnom razdoblju, 116-118.

72 JELASKA MARIJAN, Grad i ljudi: Split 1918.-1941., 217-218, 472.

73 Prema bilješci Ante Trumbića o obavijestima Josipa Torbara od 10. ožujka 1935. godine. MATKOVIĆ, TROGRLIĆ, Političke bilješke Ante Trumbića, sv. II, 43. 


\section{Splitski gradonačelnik}

Na dužnosti splitskoga gradonačelnika Buić je naslijedio inženjera Mihovila Kargotića ${ }^{74}$, koji je za kormilom splitske Općine bio pet godina. Kargotić je 18. svibnja 1938. podnio ostavku banu Primorske banovine Josipu Jablanoviću. ${ }^{75}$ Nakon njega već je idućega dana ostavku podnijela većina vijećnika zajedno s potpredsjednikom Općine Dujom Ivaniševićem. Razlozi Kargotićeve ostavke nisu izneseni javnosti. Neslužbeno je pak Kargotić izjavio da mu je pet godina, koliko je obnašao dužnost splitskoga gradonačelnika, bilo više nego dosta. ${ }^{76}$

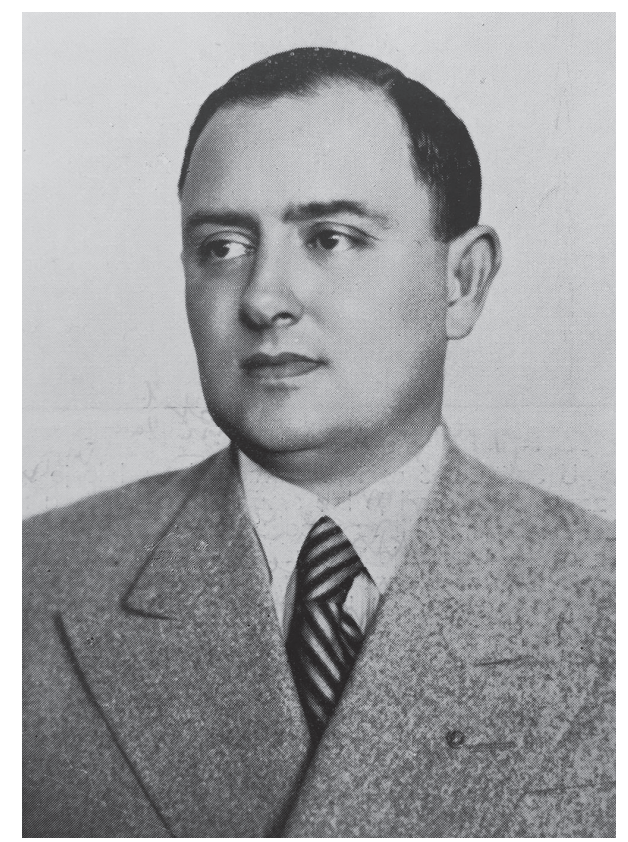

Mirko Buić (izvor: Glasnik Primorske banovine, 1. 10. 1938., 194)

74 Mihovil Kargotić (Imotski, 1891. - Split, 1987.), građevinski inženjer i splitski gradonačelnik. Premda je rođen u Imotskom, njegova je obitelj bila podrijetlom s otoka Visa. U Split se preselio kada je njegov otac Lujo, koji je bio javni bilježnik, nastavio svoju bilježničku službu u tom gradu. Nakon završene Realne gimnazije u Splitu studirao je na visokoj tehničkoj školi u Beču, Brnu, Pragu, Zürichu i Parizu. Imao je vlastito građevinsko poduzeće. Splitski gradonačelnik bio je od 1933. do 1938. godine. JELASKA MARIJAN, Grad i ljudi: Split 1918.-1941., 136-137. Za pojedine podatke o Mihovilu Kargotiću zahvaljujem kolegi iz Društva prijatelja kulturne baštine Split Stanku Piploviću.

75 Josip Jablanović (Makarska, 1875. - Split, 1961.), političar i publicist. Doktorirao je pravo u Grazu 1899. godine. Svoje prezime Cortellazo promijenio je u Jablanović. Do 1918. radio je u Financijskom odvjetništvu u Zadru. Nakon toga djelovao je kao istaknuti član Narodne radikalne stranke u Splitu. Poslije niza visokih dužnosti imenovan je na mjesto bana Primorske banovine nakon Tartagline ostavke 1932. godine. Bansku dužnost obnašao je do umirovljenja 1938. godine. PRANJKO, „Jablanović, Josip”, 212.

76 JELASKA MARIJAN, Grad i ljudi: Split 1918.-1941., 137. 
Ubrzo se kao glavni kandidat za splitskoga načelnika počeo spominjati Buić, koji je kao dugogodišnji tajnik Trgovačko-obrtničke komore u Splitu bio jako dobro upoznat s gospodarskim prilikama u gradu. Nakon što je ban Jablanović službeno dobio odobrenje za promjene u općinskoj upravi Splita, imenovao je Buića novim predsjednikom Općine, a trgovca Ivana Zlatka Vrdoljaka potpredsjednikom. ${ }^{77}$ Primopredaja vlasti obavljena je 15 . lipnja u srdačnom tonu. ${ }^{78}$

Prva sjednica Gradskoga vijeća nakon Buićeva imenovanja splitskim načelnikom održana je 22. lipnja 1938. godine. Tada je Buić zajedno s novim vijećnicima položio zakletvu. U nastupnom govoru istaknuo je da će uložiti sva svoja nastojanja da bi se komunalna politika u budućnosti vodila racionalno i zakonito te najavio da će posebnu pozornost posvetiti rješavanju socijalnih i zdravstvenih pitanja u Općini, pitanju klaonice u Splitu i Solinu te uređenju tržišta. Naglasio je da njegova gradska uprava neće zanemariti prosvjetu i kulturu i najavio da će se svim tekućim poslovima koji su od interesa za građane, kao što su pitanje vode i održavanje ulica i putova, posvetiti poseban interes te da će tražiti efikasnost i ekspeditivnost općinskih službi u njihovu rješavanju. Stavljanje u funkciju javnih skladišta apostrofirao je kao jedan od prioriteta koji bi Splitu trebao dati karakter izvoznoga i uvoznoga emporija. Završavajući govor, Buić se prisjetio natpisa na dubrovačkom Kneževu dvoru Obliti privatorum, publica curate („zaboravite privatne poslove, posvetite se javnim”). $\mathrm{Na}$ kraju sjednice vijećnici su izglasali nove članove gradskih odbora, a Buić je imenovan u upravni odbor Električnih poduzeća. ${ }^{79}$

Na sjednici Turističkoga saveza grada Splita održanoj 18. srpnja 1938. u gradskom poglavarstvu gradonačelnik Buić osvrnuo se na aktualne turističke prilike u Splitu. Istaknuo je da Split ima sve potrebne preduvjete da postane izrazito turističko mjesto, a ne samo tranzitno. Posebno je naglasio važnost izgradnje novih hotelskih kapaciteta, uređenje plaža, parkova, ali i privatnih vrtova i dvorišta. Najavio je početak izgradnje botaničkoga vrta na Mejama. ${ }^{80}$ Turistički savez Splita u rujnu 1938. potaknuo je pitanje izrade regulacijskih planova te uređivanje javnih nasada i privatnih vrtova na turističkim područjima Primorske banovine. ${ }^{81}$

Pitanje spomenika pokojnom kralju Aleksandru Karađorđeviću u Splitu postavljeno je na sjednici Gradskoga vijeća 20. srpnja 1938. godine. Natječaj za idejno rješenje spomenika bio je raspisan još u studenom 1935. godine. ${ }^{82}$ $\mathrm{Na}$ toj je sjednici Gradsko vijeće izabralo i nove članove Javne dobrotvornosti

\footnotetext{
77 Isto, 137-138.

78 „Nova općinska uprava u Splitu”, Glasnik Primorske banovine, 15. 6. 1938., 131.

79 „Prva sjednica obnovljenog gradskog vijeća”, Novo doba, 23. 6. 1938., 5.

80 „Rasprava o turističkim pitanjima grada Splita”, Novo doba, 19. 7. 1938., 5.

${ }^{81}$ PIPLOVIĆ, Izgradnja Splita izmedu svjetskih ratova, 337.

${ }^{82}$ Prvu nagradu na natječaju dobio je kipar Antun Augustinčić. Spomenik je trebao biti podignut na južnom dijelu Prokurativa, no zbog nedostatnih financijskih sredstava nikada nije postavljen. JELASKA MARIJAN, Grad i ljudi: Split 1918.-1941., 451.
} 
te prihvatilo odredbu o strogoj zabrani lijepljenja plakata osim na za to predviđenim mjestima u gradu. Usto je prihvaćen prijedlog građevinskoga pravilnika za grad Split, kao i prijedlog pravilnika fonda za izvođenje regulacije grada Splita. ${ }^{83}$

Kako je najavio u nastupnom govoru kada je preuzimao vodstvo splitske Općine, Buić se zauzeo za stavljanje u funkciju javnih skladišta na gatu sv. Duje u splitskoj luci. Premda je izgradnja skladišta dovršena još krajem 1936., ona nisu funkcionirala na zadovoljavajući način. Kapacitet im je planiran za 840 vagona, a zapravo su mogla zaprimiti najviše 600 tona robe. Tijekom gradnje skladišta nije se razmišljalo o uredskim prostorima, pa upravno osoblje nije imalo svoje urede. Da bi se ispravili nedostaci, gradonačelnik Buić sazvao je 22. kolovoza 1938. sjednicu Uprave skladišta. Na njoj je utvrđeno da su sve pravne i administrativne smetnje uklonjene te su skladišta mogla započeti s funkcionalnim radom. ${ }^{84}$

Splitska Općina s Buićem na čelu početkom kolovoza 1938. inicirala je gradnju zgrada namijenjenih radnicima. U nizu problema koji nisu mogli čekati, Buić je u prvi plan stavio rješavanje socijalnih pitanja, a među njima je na prvome mjestu bila gradnja jeftinih radničkih stanova. Velika gospodarska kriza 30-ih godina spriječila je Buićeve prethodnike na čelu splitske općinske uprave da posvete veću pozornost gradnji stanova u kojima su radnici mogli uz nisku najamninu dobiti kvalitetan stambeni prostor. ${ }^{85} \mathrm{U}$ tu je svrhu gradska uprava na čelu s Buićem zatražila od Ministarstva socijalne politike zajam u iznosu od 5.000.000 dinara. U kolovozu je u Splitu na proputovanju bio ministar socijalne politike i narodnog zdravlja Dragiša Cvetković. Njemu je Buić kao najvitalniju potrebu grada spomenuo izgradnju radničkih stanova. Cvetković je obećao poduprijeti gradnju stanova s početnim iznosom od 2.000.000 dinara. To je trebala biti prva tranša, koja je uz one buduće trebala biti osigurana iz fondova Okružnih ureda. S tim je iznosima Općina trebala podizati stanove koji bi uz buduću amortizaciju od 25 godina u obliku plaćanja najamnine prelazili u vlasništvo radnika. Općina je planirala graditi stanove po uzoru na one podignute u većim industrijskim centrima srednje Europe, koji su se pokazali funkcionalni. ${ }^{86}$

83 „Sjednica Gradskog vijeća u Splitu”, Novo doba, 21. 7. 1938., 5.

84 PIPLOVIĆ, Izgradnja Splita izmedu svjetskih ratova, 305-306.

${ }^{85}$ „Za izgradnju malih stanova”, Novo doba, 1. 8. 1938., 5; „Radnički stanovi u Splitu”, Glasnik Primorske banovine, 1. 9. 1938., 1.

${ }^{86}$ „Ministar Cvetković u Splitu”, Novo doba, 25. 8. 1938., 5; „Radnički stanovi u Splitu”, Glasnik Primorske banovine, 1. 9. 1938., 1. 


\section{Ministar u vladi Kraljevine Jugoslavije i ban Primorske banovine}

Pri rekonstrukciji vlade Milana Stojadinovića Buić je odredbom kraljevih namjesnika od 25. kolovoza 1938. imenovan ministrom tjelesnoga odgoja (fizičkog vaspitanja). ${ }^{87}$ Ministarska dužnost bila je nespojiva s gradonačelničkom, pa je to imenovanje označilo kraj Buićeva kratkotrajnoga upravljanja splitskom općinskom upravom, koju je nakon njega privremeno nastavio voditi potpredsjednik Ivan Zlatko Vrdoljak. Zasigurno je dugogodišnji rad Mirka Buića u splitskom sokolskom društvu bio važna referenca pri imenovanju za ministra tjelesnoga odgoja. Kao ministar, Buić je potpisao akt o osnivanju jednogodišnjega tečaja za obrazovanje nastavnika gimnastike po školama. ${ }^{88}$

Ministarsku dužnost Buić je obnašao još kraće nego onu splitskoga gradonačelnika jer je 20. rujna 1938., nakon umirovljenja bana Josipa Jablanovića, imenovan banom Primorske banovine. Dužnost bana preuzeo je 29. rujna nakon dolaska iz Beograda.$^{89}$ Buić je 1. listopada 1938. organizirao primanje za načelnike odjeljenja i šefove odsjeka banske uprave, koje je novom banu predstavio podban Humbert Luger. U svojem je obraćanju izrazio nadu da će u njima pronaći suradnike koji će pomoći provesti njegove zamisli za boljitak Primorske banovine. Nakon toga novom se banu uime kolega obratio podban Luger, koji je izrazio radost što je na čelo banske uprave došla osoba koju svi već dobro poznaju po vrlinama i radnim kvalitetama. Obećao mu je punu suradnju te zaželio uspjeh u svoje i ime sveg osoblja banske uprave. ${ }^{90}$

Teško gospodarsko stanje u Primorskoj banovini Buić je pokušavao pokrenuti javnim radovima. Tako je u pasivnim krajevima od studenoga 1938. do početka ožujka 1939. na javne radove banska uprava utrošila 3.700 .000 dinara. Taj je iznos bio predviđen za izvođenje radova na općinskim putovima te za manje hidrotehničke zahvate. ${ }^{91} \mathrm{Za}$ prva dva službena putovanja po Primorskoj banovini Buić je izabrao bosanskohercegovačke kotareve. Bio je srdačno primljen u Mostaru, Konjicu, Prozoru, Kupresu, Bugojnu i Tomislavgradu, gdje je njegovim rješenjem osnovana poljoprivredna stanica. Tom je prilikom posjetio i Imotski. ${ }^{92}$

Buić se tijekom pripreme banovinskoga proračuna za 1939./40. zalagao za povećanje državne pomoći. U tom je smislu uputio Vladi prijedlog za amandman Financijskoga zakona koji bi omogućio veću državnu pomoć siromašnoj Primorskoj banovini. Buić je bio svjestan da ta pomoć ne bi trajno rije-

87 „Rekonstrukcija vlade g. dra M. Stojadinovića”, Novo doba, 27. 8. 1938., 1.

88 PETRIĆ, „Sportski vremeplov. Sport u Splitu od 1941. do 1945. (5)”, Slobodna Dalmacija (Split), 17. 4. 2000., 29.

89 „Ban g. dr Buić”, Novo doba, 29. 9. 1938., 6.

90 „Načelnici Banske uprave kod bana”, Novo doba, 1. 10. 1938., 6.

91 „Banovinski proračun”, Novo doba, 2. 3. 1939., 6.

92 „Inspekciono putovanje bana po bosansko-hercegovačkim srezovima”, Glasnik Primorske banovine, 1. 11. 1938., 222-223; „Drugo inspekciono putovanje bana Primorske banovine”, Glasnik Primorske banovine, 1. 12. 1938., 237-238. 
šila problem banovinskoga proračuna, pa je predlagao i radikalnu reformu sustava financiranja banovinskih uprava. Bansko vijeće Primorske banovine nakon trodnevnoga zasjedanja prihvatilo je prijedlog proračuna za 1939./40. godinu. ${ }^{93}$ Buićevim zalaganjem kod predsjednika Vlade Dragiše Cvetkovića gotovo je u cijelosti odobren predloženi banovinski proračun za 1939./40. u iznosu od 66.795.775 dinara. Taj je iznos bio za 15.000.000 dinara veći od proračuna za prethodnu godinu. ${ }^{94}$ Njime su osigurana sredstva za pošumljavanje krša, poticanje veterinarske djelatnosti, nabavu namještaja za ukupno tri nove gimnazije u Splitu i Kninu, subvenciju splitskoga kazališta te za pomoć u gradnji Gradske biblioteke u Splitu. U tehničkoj grani predviđena su pojačana sredstva za održavanje seoskih putova, melioraciju te za opskrbu sela pitkom vodom. U zdravstvu su predviđena sredstva za obnovu dotrajaloga inventara i popravak bolnica. U industriji su rezervirana novčana sredstva za daljnju elektrifikaciju turističkih mjesta u banovini. ${ }^{95}$ Banska uprava na čelu s Buićem zauzimala se za gradnju novih i rekonstrukciju postojećih banovinskih cesta. Tako su osigurana znatna sredstva za rekonstrukciju ceste Split - Omišs. U nekoliko navrata doznačena su sredstva za gradnju lokalnih putova na Hvaru, a uložena su znatna sredstva u gradnju novih seoskih cesta u Trogirskoj zagori. Buić se zauzeo za isušivanje Sinjskoga polja. Taj je projekt imao veliku gospodarsku važnost za sinjski kraj, a osiguravao je obrađivanje 4800 hektara plodne zemlje. ${ }^{96}$

Banska uprava na čelu s Buićem odobrila je u srpnju 1939. kreditna zaduženja za razne potrebe. Tako je 100.000 dinara bilo namijenjeno za nadogradnju i proširenje bolnice u Šibeniku, a isti je iznos bio predviđen i za uređenje moderne praonice i sušionice banovinske bolnice te za potrebe uređenja prometa između Supetra i Sutivana i rekonstrukciju banovinskih cesta. Za popravak i uređenje škola u Sitnom Gornjem, Zadvarju, Svinišću i Podgori odobren je iznos od ukupno 135.000 dinara. ${ }^{97}$

Energičan start Mirka Buića na čelu Primorske banovine uskoro je došao kraju zbog ustrojstvene reforme Kraljevine Jugoslavije. Naime, sporazumom Cvetković-Maček od 26. kolovoza 1939. uspostavljena je Banovina Hrvatska na čelu s banom Ivanom Šubašićem. Banovina Hrvatska obuhvaćala je područja s većinskim hrvatskim stanovništvom: Savsku i Primorsku banovinu te kotareve Dubrovnik, Ilok, Šid, Brčko, Gradačac, Derventa, Travnik i Fojnica. ${ }^{98}$

93 „Zasjedanje banovinskog vijeća”, Novo doba, 6. 3. 1939., 6-7; „Bansko vijeće raspravlja o proračunu”, Novo doba, 7. 3. 1939., 6; „Zaključeno zasjedanje banskog vijeća”, Novo doba, 8. 3. 1939., 6.

94 „Odobren proračun Primorske banovine”, Novo doba, 1. 4. 1939., 5; Glasnik Primorske banovine, 1. 5. 1939., 87-89.

95 „Budžet Primorske banovine za god. 1939-40”, Glasnik Primorske banovine, 1. 5. 1939., 101-102.

96 Glasnik Primorske banovine, 1. 7. 1939., 135.

97 „Banska uprava odobrila kredite”, Novo doba, 24. 7. 1939., 6.

98 Detaljnije o sporazumu Cvetković-Maček i nastanku Banovine Hrvatske vidi u: BOBAN, Sporazum Cvetković-Maček. 
Formiranjem Banovine Hrvatske likvidirani su upravni organi Primorske banovine. Za područje bivše Primorske banovine, kojima su dodani kotarevi Dubrovnik, Fojnica i Travnik, uspostavljen je posebni organ pravne vlasti - Ispostava banske vlasti u Splitu. Dotadašnji podban Primorske banovine Humbert Luger imenovan je vršiteljem dužnosti povjerenika Ispostave. ${ }^{99}$

\section{Drugi svjetski rat i smiraj života u Rimu}

Izvori za podatke o životu i djelovanju Mirka Buića nakon početka Drugoga svjetskog rata pa do njegove smrti, u usporedbi s onima za prethodno razdoblje, dosta su šturi, pa bi se ta njegova životna faza tek trebala dodatno rasvijetliti. Nekoliko dana nakon raspada Kraljevine Jugoslavije i uspostave kvislinške Nezavisne Države Hrvatske 10. travnja 1941., Buić je uhićen zajedno s bivšim banovima Ivom Tartagliom i Josipom Jablanovićem te nizom istaknutih Splićana koji su obnašali razne rukovodeće dužnosti za vrijeme Kraljevine Jugoslavije. Uskoro je ipak pušten iz zatvora. ${ }^{100}$

U dostupnoj literaturi spominje se Buićeva aktivnost kod fašističkih vlasti u Splitu s ciljem zaštite srpskoga stanovništva u Nezavisnoj Državi Hrvatskoj. Publicist Sibe Kvesić, citirajući glasilo Naš izvještaj, navodi da je krajem kolovoza 1941. Buić u delegaciji s pravoslavnim svećenikom u Splitu Sergijem Urukalom posjetio fašističkoga prefekta Zerbina da bi pokušao zaštititi srpsko stanovništvo na području Nezavisne Države Hrvatske. ${ }^{101}$ Drago Gizdić navodi da je zbog pregovora s fašistima Buić u to vrijeme u komunističkom pokretu otpora smatran suradnikom okupatora. ${ }^{102}$

Buić je bio jedan od osnivača organizacije Građanski blok, utemeljene u Splitu krajem studenoga 1942. godine. U tu organizaciju ušli su neki bivši pripadnici Hrvatske seljačke stranke, bivši pristaše Jugoslavenske nacionalne stranke te bivši pripadnici Orjune poput Nike Bartulovića, tj. uglavnom osobe koje su prije rata bile unitarne jugoslavenske orijentacije. Namjera organizacije bila je u prvom redu nametnuti se kao protuteža gradskom narodnooslobodilačkom odboru (NOO), ali u tome njezini članovi nisu postigli veći uspjeh. ${ }^{103}$

Početkom rujna 1943. formirano je savjetodavno tijelo pri NOO-u Split od bivših članova građanskih stranaka. U njega su, uz ostale, ušli bivši banovi

\footnotetext{
99 BARČOT, „Ispostava banske vlasti Banovine Hrvatske u Splitu 1939.-1941.”, 673-682.

100 Uhićeni su 12. travnja 1941. godine. KUZMIĆ, Antifašistički Split, 31.

101 Naš izvještaj tiskao se kao glasilo Pokrajinskoga komiteta Narodnooslobodilačkoga pokreta u Republici Hrvatskoj. KVESIĆ, „Naš izvještaj - mobilizator masa u borbi protiv fašizma”, 153.

${ }^{102}$ GIZDIĆ, Dalmacija 1942., 700. U biografskom leksikonu banova Kraljevine Jugoslavije stoji da je Buić bio „blizak rojalističkom pokretu otpora kao član Srpskog nacionalnog komiteta u Splitu”. GULIĆ, „Buić Mirko”, 37.

${ }^{103}$ GIZDIĆ, Dalmacija 1942., 700-701; BOŠKOVIĆ, Orjuna - ideologija i književnost, 271-
} 272 . 
Primorske banovine Buić i Jablanović. Drago Gizdić piše da je to tijelo osnovano da bi se preduhitrila ideja bivših suradnika okupatora o uspostavi određenoga političkog tijela koje bi se suprotstavilo NOO-u. Gizdić dalje ističe da je taj odbor radio na okupljanju oko Narodnooslobodilačkoga pokreta onih koji se nisu odviše kompromitirali u suradnji s okupatorom. ${ }^{104}$

Pri povlačenju talijanske vojske iz Splita u rujnu 1943. u eksploziji je stradala obiteljska kuća Mirka Buića na Matejuški. ${ }^{105}$ Nakon kapitulacije Italije Savjetodavni odbor NOO-a u Splitu rasformirao se, a dio njegovih članova, uključujući Mirka Buića, povukao se zajedno s partizanima prije ulaska njemačke vojske u Split. ${ }^{106}$ Buić je dakle nakon talijanske kapitulacije sa sinom Đorđem i nekolicinom prijatelja prešao na oslobođeni teritorij na Visu. Smrt sina, koji je zbog poznavanja engleskoga jezika postao osobni prevodilac Randolpha Churchilla, sina britanskoga premijera Winstona Churchilla, duboko ga je pogodila. U smiraj rata otišao je u Rim, gdje je živio sve do smrti. ${ }^{107}$ Prema navodima njegove kćeri Jagode, ondje se bavio proučavanjem starih rukopisa u Vatikanskoj biblioteci. ${ }^{108}$ Buić je umro u Rimu 19. lipnja 1967., ${ }^{109}$ a njegovi posmrtni ostaci preneseni su u Split. ${ }^{110}$ Iz Splita su potom Buićevi posmrtni ostaci preneseni u Stari Grad gdje je i sahranjen. ${ }^{111}$

\section{Zaključak}

Na temelju iznesenih biografskih podataka može se zaključiti da je Buić imao istaknute organizacijske sposobnosti, koje je dokazao na više područja svojega djelovanja u Splitu, gdje je i proveo najdulju životnu dionicu. Bio je svestrana ličnost: pravnik, poduzetnik, publicist, sokolski starješina te visoki lokalni i državni dužnosnik za vrijeme Kraljevine Jugoslavije. Po svojim političkim stajalištima bio je blizak beogradskim vladajućim krugovima te neupitno unitarno jugoslavenski orijentiran. S obzirom na to da ipak nije bio

104 GIZDIĆ, Dalmacija 1943., 513.

105 „Intervju Jagode Buić 'Blicu' - Šerbedžija mi je ulepšavao život”, Blic (Beograd), on-line izdanje, 25. 1. 2009., pristup ostvaren 30. 4. 2020., https://www.blic.rs/intervju/serbedzija-mi-je-ulepsavao-zivot/vj9xr18.

106 GIZDIĆ, Dalmacija 1943., 513; GULIĆ, „Buić Mirko”, 37.

107 „Intervju Jagode Buić ‘Blicu’ - Šerbedžija mi je ulepšavao život”, Blic, https://www.blic. rs/intervju/serbedzija-mi-je-ulepsavao-zivot/vj9xr18.

108 Premda Buićeva kći Jagoda u intervjuu beogradskom Blicu kaže da je njezin otac u Vatikanskoj biblioteci završio studij paleografije, u zborniku radova izdanom 1986. povodom 100. godišnjice Vatikanske škole za paleografiju u popisu osoba koje su završile tu školu nije naveden Mirko Buić. Isto; NATALINI, Cento anni di cammino.

109 HR-DAST-179-MK, sign. 582, sv. Duje, str. 120, upis br. 50.

110 U natuknici o Mirku Buiću u monografiji Banovi Kraljevine Jugoslavije. Biografski leksikon pogrešno se navodi da je on sahranjen u Splitu. GULIĆ, „Buić Mirko”, 37.

111 Zahvaljujem na podatku o posljednjem počivalištu Mirka Buića prof. Anti Rendiću Miočeviću i dr. sc. Mladenku Domazetu. Na potvrdi ovog podatka zahvaljujem odvjetniku i publicistu iz Starog Grada Vinku Ruževiću (rođ. 1927), koji se sjeća kako je Buićev olovni lijes, zbog velike težine, prenesen do njegovog groba u Starom Gradu na kočiji s konjima. 
politički aktivan u stranačkom životu međuratnoga Splita, može ga se smatrati tehnokratskim tipom javnoga dužnosnika. Vrijeme obnašanja dužnosti bana Primorske banovine i one splitskoga gradonačelnika bilo je prekratko da bi mogao napraviti neke veće iskorake, no ipak se uspio iskazati s nekoliko zapaženih inicijativa na gospodarskom planu, za što je imao kvalifikacije kao dugogodišnji tajnik u splitskoj Trgovačko-obrtničkoj komori. Nakon vrhunca karijere krajem međuratnoga razdoblja, kada je obnašao gradonačelničku, ministarsku i bansku dužnost, uslijedile su za Buića i njegovu obitelj teške i neizvjesne godine u Drugom svjetskom ratu. U političkom životu ratnoga Splita pokušao se aktivirati u okviru Građanskoga bloka, koji je okupljao uglavnom pristaše bivše monarhističke Jugoslavije, ali bez bitnijega traga. Buićevo aktiviranje u savjetodavnom tijelu NOO-a u Splitu u rujnu 1943. pomoglo je njemu i obitelji da prijeđu na teritorij oslobođenoga Visa. Životna tragedija i gubitak sina Đorđa obilježili su posljednje razdoblje njegova života, koje je proveo u Rimu, gdje je i preminuo. 


\section{Neobjavljeni izvori}

HR-DAST-91-TOK: Hrvatska, Državni arhiv u Splitu, Split, fond 91, Trgovačko-obrtnička komora Split.

HR-DAST-179-MK: Hrvatska, Državni arhiv u Splitu, Split, 179, Zbirka matičnih knjiga.

\section{Objavljeni izvori i literatura}

BARČOT, Tonko. „Ispostava banske vlasti Banovine Hrvatske u Splitu 1939.-1941." Radovi Zavoda za povijesne znanosti HAZU u Zadru 48 (2006): 667-702. Pristup ostvaren 25. 4. 2020. https://hrcak.srce.hr/index.php?show=clanak\&id_clanak_jezik=18317.

BARIĆ, Joško; JURIŠIĆ, Šimun. Splitsko iverje 1882-1941. Split: Naučna biblioteka, 1983.

BARTULOVIĆ, Niko. Od revolucionarne omladine do Orjune. Split: Izdanja Direktoriuma Orjune, 1925.

BEZIĆ-BOŽANIĆ, Nevenka. „SPLIT A. D. 1897.” Kulturna baština 28-29 (2011), br. 1: 199-214.

Blic (Beograd), 2009.

BOBAN, Ljubo. Sporazum Cvetković-Maček. Beograd: Štamparsko preduzeće Kultura, 1965.

BOBAN, Ljubo; JELIĆ, Ivan, ur. Život i djelo Ante Trumbića. Prilozi sa znanstvenog skupa. Zagreb: Hrvatska akademija znanosti i umjetnosti, 1991.

BOŠKOVIĆ, Ivan. Orjuna - ideologija i književnost. Split: Hrvatska sveučilišna naklada, 2006.

BUBLE, Sanja. „Hrvatski dom Kamila Tončića u Splitu”. Prilozi povijesti umjetnosti u Dalmaciji 42 (2011), br. 1: 414-441.

CAMBI, Nenad; STIPČEVIĆ-DESPOTOVIĆ, Anđelka. „Bulić, Frane”. U: Hrvatski biografski leksikon (mrežno izdanje). Leksikografski zavod „Miroslav Krleža”. Pristup ostvaren 6. 4. 2020. http://hbl.lzmk.hr/clanak.aspx?id=3127.

ČIPČIĆ, Marijan, ur. Ante Trumbić - biografski fragmenti i nasljeđe. Zbornik radova sa znanstvenog skupa „Dr. Ante Trumbić (1864. - 1938.) - osam desetljeća od smrti” održanog 15. studenoga 2018. godine u Muzeju grada Splita. Split: Muzej grada Splita; Društvo prijatelja kulturne baštine Split, 2020.

ČIPČIĆ, Marijan. Splitski gradonačelnici (1882. - 1918.): život i uspomene. Split: Muzej grada Splita, 2019.

ČIPČIĆ, Marijan. „Splitski gradonačelnik Vinko Katalinić (1857.-1917.)”. Kulturna baština 44 (2018), br. 1: 201-222.

ČIPČIĆ, Marijan; PERKO KERUM, Darka; DUKIĆ, Josip. Ante Trumbić - Patricij s Lučca. Split: Muzej grada Splita, 2019.

DOMAZET, Mladenko. Stari Grad na Hvaru. Otočni grad na razmeđu 19. i 20. stoljeća. Stari Grad: Muzej Staroga Grada, 2011. 
FRIEDL, Vesna, ur. Gospodarska komora u Splitu 1808.-2008. Split: HGK, Županijska komora, 2008.

GIZDIĆ, Drago. Dalmacija 1942. Prilog historiji Narodnooslobodilačke borbe. Zagreb: Izdavačko odjeljenje Glavnog odbora saveza boraca Hrvatske, 1959.

GIZDIĆ, Drago. Dalmacija 1943. Prilog historiji Narodnooslobodilačke borbe. Zagreb: Epoha, 1962.

Glasnik Primorske banovine (Split), 1938-1940.

GULIĆ, Milan. „Buić Mirko”. U: Banovi Kraljevine Jugoslavije. Biografski leksikon, ur. Momčilo Pavlović, Predrag Vajagić i Nebojša Stambolija. Beograd: Institut za savremenu istoriju, 2019., 37-38.

IVANIŠEVIĆ, Milan. „Uglednici iz splitskog roda Bulata”. Kulturna baština 42-43 (2017), br. 1: 51-60.

Izvještaj Trgovačko-obrtničke komore za god. 1928.-1928. Split: Narodna tiskara „Novo doba”, 1929.

JAKIR, Aleksandar. Dalmacija u međuratnom razdoblju 1918. - 1941. Zagreb: Lekyam international, 2018.

JAKIR, Aleksandar; BULJAN, Marijan, ur. Ivo Tartaglia: političar i intelektualac. Zbornik radova s medunarodnog znanstvenog skupa „Ivo Tartaglia i njegovo doba" održanog od 23. do 24. rujna 2013. godine u Splitu. Split: Književni krug Split, 2016.

JAKOVČEV, Gojko. Sokolska organizacija u borbi za bratstvo jugoslavenskih naroda do 1918 godine. Progon sokolske organizacije u Hrvatskoj. Zagreb: Savezna komisija za historiju fizičke kulture Jugoslavije, 1970.

JELASKA MARIJAN, Zdravka. Grad i ljudi: Split 1918.-1941. Zagreb: Hrvatski institut za povijest, 2009.

KOVAČIĆ, Joško. „Splitski liječnik i političar Jakša Račić”. Kulturna baština 28-29 (1997), br. 1: 257-258.

KOVAČIĆ, Mihaela. dr. Ivo Tartaglia (1880.-1949.). Arhiv Ive Tartaglie u Sveučilišnoj knjižnici u Splitu. Split: Sveučilišna knjižnica u Splitu, 2013.

KOVAČIĆ, Mihaela. „Dr. Ante Trumbić: životopis kroz spise osobnog arhiva u Sveučilišnoj knjižnici u Splitu”. U: Dr. Ante Trumbić (1864.-1938.). Životopis kroz spise osobnog arhiva u Sveučilišnoj knjižnici u Splitu. Katalog u povodu 150. obljetnice rođenja dr. Ante Trumbića, ur. Mihaela Kovačić i Marko Trogrlić. Split: Sveučilišna knjižnica u Splitu; Filozofski fakultet u Splitu, 2015, 11-47.

KOVAČIĆ, Mihaela; TROGRLIĆ, Marko, ur. Dr. Ante Trumbić (1864. 1938.). Životopis kroz spise osobnog arhiva u Sveučilišnoj knjižnici u Splitu. Katalog u povodu 150. obljetnice rođenja dr. Ante Trumbića. Split: Sveučilišna knjižnica u Splitu; Filozofski fakultet u Splitu, 2015.

KUZMIĆ, Marin, ur. Antifašistički Split. Ratna kronika 1941-1945. Split: Udruga antifašističkih boraca i antifašista Splita, 2010. 
KVESIĆ, Sibe. „Naš izvještaj - mobilizator masa u borbi protiv fašizma”. U: Split u Narodnooslobodilačkoj borbi i socijalističkoj revoluciji 1941.-1945., ur. Miroslav Ćurin. Split: Institut za historiju radničkog pokreta Dalmacije, 153-158.

MACHIEDO MLADINIĆ, Norka. Životni put Ive Tartaglie. Split: Književni krug Split, 2001.

MAROVIĆ, Duško; RADJA, Mihovil. Povijest športa u Splitu, knj. 2: 1918. - 1941. Split: Splitski savez športova, Komisija za povijest športa, 2006.

MATKOVIĆ, Stjepan; TROGRLIĆ, Marko, prir. Političke bilješke Ante Trumbića 1930. - 1938., sv. II (1935. - 1938.). Zagreb; Split: Hrvatski institut za povijest; Odsjek za povijest Filozofskog fakulteta u Splitu, 2019.

MOROVIĆ, Hrvoje. Građa za bibliografiju splitske periodike - Novine 1875 - 1941. Split: Naučna biblioteka, 1968.

Nacional (Zagreb), 2015.

NATALINI, Terzo, ur. Cento anni di cammino. Scuola Vaticana di Paleografia, Diplomatica e Archivistica (1884-1984). Vatikan, 1986.

NOVAK, Grga. Povijest Splita, knj. 3. Split: Matica hrvatska, 1965.

Novo doba (Split), 1931, 1938-1939.

OBAD, Stijepo. „Biankini, Juraj”. U: Hrvatski biografski leksikon (mrežno izdanje). Leksikografski zavod „Miroslav Krleža”. Pristup ostvaren 7. 4. 2020. http://hbl.lzmk.hr/clanak.aspx?id=1919.

PERIĆ, Ivo. Ante Trumbić na dalmatinskom političkom poprištu. Split: Muzej grada Splita, 1984.

PERIĆ, Ivo; SIROTKOVIĆ, Hodimir. „Politička djelatnost i politički lik Josipa Smodlake". U: Izabrani spisi Josipa Smodlake, ur. Ivo Perić i Hodimir Sirotković. Split: Književni krug Split, 1989, 9-203.

PETRINOVIĆ, Ante. Ante Trumbić - politička shvaćanja i djelovanje. Drugo izdanje. Split: Književni krug Split, 1991.

PIPLOVIĆ, Stanko. „Izgradnja doma Trgovačke i obrtničke komore u Splitu”. Kulturna baština 40 (2014), br. 1: 191-210.

PIPLOVIĆ, Stanko. Izgradnja Splita između svjetskih ratova. Split: Društvo prijatelja kulturne baštine Split, 2008.

POŽAR, Petar. Znameniti i zaslužni Splićani te spomena vrijedne osobe $u$ splitskoj povijesti (1700 godina). Split: Vlastita naklada, 2001.

PRANJKO, Klara. „Jablanović, Josip”. U: Hrvatski biografski leksikon, sv. 6. Zagreb: Leksikografski zavod „Miroslav Krleža”, 2005, 212.

Privrednička riječ (Split), 1928-1929, 1932.

RADICA, Branislav. Novi Split. Monografija grada Splita od 1918. do 1930. godine. Split: Hrvatska štamparija Gradske štedionice, 1931.

RENDIĆ-MIOČEVIĆ, Ante. „Dr. Duje Rendić-Miočević, prvi splitski narodnjački gradonačelnik”. Kulturna baština 44 (2018), br. 1: 13-38. 
Sletski vijesnik Sokolske župe Split (Split), 1923.

Slobodna Dalmacija (Split), 2000.

Službeni glasnik: zvanični list Splitske i Dubrovačke oblasti (Split), 1924.

SMITH PAVELIĆ, Ante. Dr. Ante Trumbić: problemi hrvatsko-srpskih odnosa. München: Knjižnica Hrvatske revije, 1959.

SMODLAKA, Josip. Zapisi. Zagreb: Jugoslavenska akademija znanosti i umjetnosti, Razred za društvene nauke, 1972.

Sokol na Jadranu (Split), 1926, 1931.

„Tartaglia, Ivo”. U: Hrvatska enciklopedija (mrežno izdanje). Leksikografski zavod „Miroslav Krleža”. Pristup ostvaren 14. 9. 2020. https://www.enciklopedija.hr/Natuknica.aspx?ID=60487.

TARTAGLIA-KELEMEN, Vladimira. „Buić, Jagoda”. U: Hrvatski biografski leksikon (mrežno izdanje). Leksikografski zavod „Miroslav Krleža”. Pristup ostvaren 8. 4. 2020. https://hbl.lzmk.hr/clanak.aspx?id=3070.

Zapisnik I. redovite plenarne sjednice Trgovinsko industrijske komore u Splitu, održane 18. svibnja 1938. [Split], 1938.

Zapisnik II. redovite komorske sjednice održane 28 listopada 1924 godine. [Split], 1924.

Zapisnik II. redovite komorske sjednice održane dne 11. oktobra 1934. [Split], 1934. 


\section{Mirko Buić (1894-1967): A Biographical Sketch of a Split Mayor and a ban of the Littoral Banate}

On the basis of unpublished material, periodicals, and printed matter as well as reference literature, this paper offers a reconstruction of a part of the biography of Dr Mirko Buić, a prominent personality of public life in Split between the world wars. Buićs political orientation was unambiguously Yugoslav and pro-royalist, though he never actively participated on the political stage of interwar Split. In the professional sense, Buić left the deepest impression on the Chamber of Trades and Crafts in Split, where he acted as secretary from late 1924 to mid-1938, when he was appointed as the mayor of Split. For a short time, Buić served as the mayor of Split and the Minister of Physical Education of the Kingdom of Yugoslavia. Mirko Buić was the ban (governor) of the Littoral Banate from September 1938 until the new administrative division of the Kingdom of Yugoslavia and the formation of the Banate of Croatia were implemented following the Cvetković-Maček Agreement in August 1939. In addition to his professional work, Buić made a significant impression on the Sokol Society of Split, where he played a leading role through most of the interwar period.

His short tenures as ban of the Littoral Banate and mayor of Split were too brief for Buić to make significant changes, but he was nonetheless responsible for some noted initiatives in the economic field. After achieving the peak of his career in the late interwar period, when he was mayor, minister, and ban, the years of World War II were ones of hardship and uncertainty for Buić and his family. Buićs active participation in the advisory body of the People's Liberation Committee in Split in September 1943 helped him and his family reach the liberated territory of Vis. Near the end of the war he moved to Rome, where he lived out his remaining years.

Key words: Mirko Buić; Split; lawyer; mayor; ban (governor); minister; Littoral Banate; Kingdom of Yugoslavia; Sokol society; Chamber of Trades and Crafts 